\title{
PENGARUH REMEDIAL LANSUNG TERHADAP HASIL BELAJAR SISWA PADA MATA PEMEBELAJARAN MATEMATIKA KELAS V DI SD NEGERI SIKAPA KABUPATEN BARRU
}

\author{
Damayanti Tamrin, Ernawati \\ Pendidikan Guru Sekolah Dasar, Fakultas Keguruan dan Ilmu Pendidikan \\ Universitas Muhammadiyah Makassar \\ damayantitamrin2@gmail.com
}

\begin{abstract}
Abstrak
Tujuan penelitian adalah untuk mengetahui Pengaruh Remedial Lansung Terhadap Hasil Belajar Siswa Pada Mata Pembelajaran Matematika. Penelitian dilaksanakan pada tanggal 18 Juli 2017 di SD Negeri Sikapa Kabupaten Barru dengan memilih 14 orang Siswa sebagai sampel dari kelas V, sedangkan pengumpulan data menggunakan Tes Awal, Tes Akhir dan Dokumentasi. Hasil analisis data pengaruh Remedial Lansung terhadap Hasil belajar Siswa Pembelajaran Matematika terlihat bahwa nilai $\mathrm{t}$ hitung yaitu 11,41 sedangkan $\mathrm{t}$ tabel yaitu 2,16. Oleh karna itu, perbandingan $t$ hitung dengan $t$ tabel yaitu 11,41>2,16. Dengan demikian dapat diketahui bahwa $t$ hitung lebih besar dari pada nilai $t$ tabel. Berdasarkan kriteria pengujian hipotesis yaitu: Ada pengaruh Remedal Lansung terhadap hasil belajar pada pembelajaran Matematika kelas V SD Negeri Sikapa Kabupaten Barru. Apabila nilai hitung lebih besar atau sama dengan nilai tabel, maka hipotesis yang berbunyi: tidak ada pengaruh Remedal Lansung terhadap hasil belajar pada pembelajaran Matematika kelas V SD Negeri Sikapa Kabupaten Barru di tolak. Dengan demikian, maka hipotesis alternalitif yang berbunyi: terdapat pengaruh Remedal Lansung terhadap hasil belajar pada pembelajaran Matematika kelas V SD Negeri Sikapa Kabupaten Barru di terima. Hal ini dapat dinyatakan bahwa Hasil belajar Siswa pada pembelajaran Matematika kelas V SD Negeri Sikapa Kabupaten Barru meningkat dengan diterapkannya Remedial Lansung.
\end{abstract}

Kata kunci: Pengaruh Hasil Belajar, Pembelajaran Matematika,Remedial Lansung 


\section{PENDAHULUAN}

Kemajuan ilmu pengetahuan dan teknologi adalah dua hal yang menjadi indikator terhadap tingkat perkembangan dan kemajuan suatu bangsa. Untuk mencapai kedua hal tersebut, maka bangsa harus mengupayakan perkembangan pendidikan berbagai tingkat yaitu tingkat dasar, tingkat menengah, maupun tingkat perguruan tinggi.

Abu Ahmadi dan Nur Uhbiyati, (2001:70)Pendidikan merupakan suatu keharusan dalam kehidupan manusia yang merupakan suat kegiatan, usaha yang direncanakan maupun tidak direncanakan. Usaha dan kegiatan tersebut mengarah pada kegiatan mempengaruhi, memberi contoh, dorongan, bimbingan dan latihanlatihan kepada orang dalam merbah pengetahuan, keterampilan maupun sikap. Bila hal ini dapat diwujudkan maka akan terlihat sosok manusia yang senantiasa bertaqwa terhadap Tuhan yang Maha Esa dan berbudi pekerti luhur. Adalah suatu kegiatan yang secara sadar dan disengaja serta penuh tanggung jawab yang dilakukan oleh orang dewasa kepada anak ddiknya sehingga timbul interaksi dai keduanya agar anak tersebut mencapai kedewasaan yang dicita-citakan dan berlangsung terus menerus. Pendidikan juga merupakan elemen yang vital dalam menciptakan sumber daya manusia. Tak heran jika saat ini pemerintah memberikan perhatian yang ekstra pada sektor pendidikan ini. Tentunya hal ini ditujukan untuk pengembangan pendidikan agar menjadi lebih baik dan mapu bersaing di kacah dunia. Ranah pendidikan yang berkualitas ini bukan hanya kualitas dari segi ranah kognitif saja. Namun afektif dan psikomotorik juga menjadi hal yang sangat penting dalam pembenutkan diri peserta didik. Hal ini juga dirasakan sangat penting mengingat keadaan remaja dan peserta didik kita saat ini pada umumnya telah terpengaruh oleh arus globalisasi yang belakangan berlangsung dengan sangat cepat. Apalagi teknologi informasi dan komunikasi yang semakin berkembang mau tidak mau akan sangat banyak digeluti pada kehidupan para remaja kita. Hal ini tentu harus menjadi perhatian khusu, karena arus globalisas ini tak dapat ditolak jika tidak mau menjadi negara yang tertinggal dari negara-negara lain yang artinya kita harus memberikan altrnatif pencegahan dan penanggulangan terhadap krisis yang terjadi pada para remaja, salah satunya adalah melalui pendidikan. Dalam keseluruhan proses pendidikan di sekolah, kegiatan belajar merupakan kegiatan yang paling pokok. Berhasil atau tidaknya tujuan pendidikan tergantung bagaimana proses belajar antara pendidik dan peserta didik. Untuk itu sekolah sebagai lembaga pendidikan formal menjadi wadah intelektual para individu terutama peserta didik agar menjadi insan yang handal serta berkualitas. Belajar tuntas merupakan salah satu usaha inovasi 
pendidikan yang bertujuan untuk meningkatkan motivasi belajar siswa, karena strategi pembelajaraan di Indonesia sekarang berorientasi kepada :

a.Tujuan intruksional yang hendak dicapai

b.Prinsip belajar tuntas

Ischak S.W, ( 2002:07) Berdasarkan hal diatas sangat diperlukan suatu proses pembelajaran agar bahan yang dipelajari dapat sepenuhnya dikuasai oleh seluruh peserta didik (siswa). Depdiknas, (2004 :13), Pembelajaran yang demikian dinamakan belajar tuntas (mastery learning). Untuk dapat menentukan ketuntasan atau tercapainya tujuan pendidikan dan pelajaran perlu dilakukan usaha, yaitu kegiatan untuk menilai hasil belajar. Penilaian hasil belajar bertujuan untuk melihat kemajuan belajar peserta didik dalam hal penguasaan materi pelajaran yang telah dipelajari, serta penilaian sangat di perlukan untuk dapat melihat pencapaian kompetensi dan kecenderungan tinggi rendahnya ketuntasan hasil belajar yang dicapai siswa. Ada pun jenis penilaian dilihat dari bentuk jawaban dan tujuan penilaian dapat dibedakan menjadi dua yaitu tes dan no tes. Bentuk tes lebih banyak digunakan mengungkap hasil belajar yang tidak dapat diukur dengan tes seperti sikap dan kepribadian.

Berdasarkan hasil penyelenggaraan Tes Awal dan Tes Akhir tersebut maka akan diketahui bahwa ada siswa yang belum tuntas, gagal dalam menguasai tujuan-tujuan pembelajaran serta kompetensi dasar (KD) yang hendak dicapai. Maka suatu kenyataan bahwa dalam proses belajar mengajar selalu ada siswa yang memerlukan bantuan, baik dalam mencerna bahan pelajaran maupun dalam mengatasi kesulitan-kesulitan belajar mereka. Dengan dapatnya diatasi kesulitan belajar siswa, maka siswa diharapkan dapat menguasai materi ajar yang dipelajari sehingga semua bisa menguasai kompetensi dasar (KD) yang hendak dicapai. Dengan terkuasainya kompetensi dasar, berarti siswa sudah tuntas dalam suatu materi ajar yang disampaikan. Menggunakan pola belajar tuntas lebih mmperhatikan karakteristik siswa secara individual. Karena secara individual siswa berbeda dalam cara belajar.

Hal ini dilakukan agar setiap siswa dapat berkembang secara penuh dan menguasai bahan pelajaran secara tuntas. Dalam proses pembelajaran guru sering mengalami kekecewaan dan ketidakpuasan terhadap apa yang sudah diajarkan kepada siswa disaat dilaksanakan evaluasi blajar seperti ulangan harian. Hasil diperoleh sangat jauh dari apa yang diharapkan guru tersebut. Padahal ini bisa terjadi karena kemampuan setiap siswa berbeda.Melihat kenyataan yang dihadapi, para guru menyadari bahwa dalam proses belajar mengajar selalu ada siswa yang mengalami masalah kesulitan belajar. Kesulitan belajar ini memerlukan suatu penanganan khusus dari guru. Karna itu program pembelajaraan yang tepat akan 
memberi suatu tujuan yang akan dicapai. Dengan demikian penggunaan metode mengajar yang tepat merupakan alternatif dalam usaha meningkatkan mutu pembelajaraan.

Beberapa metode pembelajaraan merupakan sarana untuk memahami perubahan tingkah laku dan perkembangan pribadinya. Oleh karena itu guru sebaiknya mengembangkan metode mengajar yang tepat agar tujuan pendidikan dan pembelajaraan dapat tercapai sesuai dengan yang diharapkan. Untuk mencapai program pembelajaraan yang tepat, maka diadakan pelayanan terhadap siswa yang mengalami masalah kesulitan belajar yaitu dengan memberi program pembelajaraan remedial. Wijaya, (1996:46),

Gerakan pendidikan dan pembelajaraan remedial memberi harapan baik terhadap murid-murid yang mengalami kesulitan belajar. Apabila kesulitan belajar itu tidak ditangani secara serius, maka kegagalan akan dialami selama-lamanya. Kegiatan remedial mencakup segala bantuan yang diberikan kepada siswa, baik pada siswa yang lambat mencerna materi pelajaran, menemui kesulitan, maupun yang gagal dalam mencapai tujuan pembelajaraan tersebut. Kegiatan remedial dalam proses belajar mengajar adalah salah satu bentuk kegiatan pemberian bantuan kepada siswa. Pemeberian bantuan didalam proses belajar mengajar yang berupa kegiatan perbaikan yang terprogram dan disusun secara sistematis. Pelaksanaan remedial dalam proses belajar mengajar yang utama adalah melayani para siswa yang mengalami kelambatan, kesulitan atau kegagalan belajar dalam mencapai intruksional yang hendak dicapai yaitu dengan memberikan bantuan atau bimbingan belajar yang berupa kegiatan perbaikan. Di SD Negeri Sikapa, sudah dilakukan kepada para siswa yang lamban dalam mencerna materi pelajaran, menemui kesulitan, yang gagal mencapai tujuan pembelajaraan atau kepada siswa yang nilainya tidak memenuhi SKBM (Standar Ketuntasan Belajar Minimal) yang telah ditetapkan oleh sekolah. Adapun standar ketuntasan belajar minimal yang ditetapkan oleh sekolah khususnya pada bidang studi Matematika adalah dengan bobot 75 . Jadi bagi siswa yang tidak mencukupi nilai yang ditetapkan maaka diberikan kesempatan kepada mereka untuk memperbaiki nilainya. Kegiatan ini disebut dengan istilah kegiatan remedial.

Pelaksanaan Remedial yang dilakukan oleh guru diharapkan dapat mengembangkan dan meningkatkan hasil belajar siswa, memberikan pemahaman kepada siswa yang belum tuntas dalam proses belajar mengajar, dan membuat siswa yang lamban atau gagal dalam proses belajar mengajar menjadi tuntas dari pembelajaran yang dilakukan.

\section{Rumusan Masalah}


Apakah terdapat pengaruh remedial langsung terhadap hasil belajar siswa pada mata pelajaran Matematika kelas V di SD Negeri Sikapa kab. Barru?

\section{Tujuan Penelitian}

Untuk mengetahui pengaruh remedial langsung terhadap hasil belajar siswa pada mata pelajaran Matematika kelas V di SD Negeri Sikapa kab. Barru

\section{A. KAJIAN TEORI}

\section{Pengertian Remedial}

Remedial (pembelajaraan perbaikan) adalah suatu bentuk pembelajaraan yang bersifat menyembuhkan, membetulkan atau pembelajaraan yang membuat menjadi baik.

Ahmadi, (2004 : 152) Maka pembelajaraan perbaikan (remedial) itu adalah bentuk khusus pembelajaraan yang berfungsi menyembuhkan, membetulkan atau membuat jadi baik. Seperti yang telah kita ketahui dalam proses belajar mengajar siswa diharapkan dapat mencapai hasil sebaik-baiknya sehingga bila ternyata ada siswa yang belum berhasil sesuai dengan harapan maka diperlukan suatu pembelajaraan yang membantu agar tercapai hasil yang diharapkan. Dengan dmikian perbaikan diarahkan kepada pencapaian hasil yang optimal sesuai dengan kemampuan masing-masing siswa melalui keseluruhan proses belajar mengajar dan keseluruhan pribadi siswa.

Dapat dikatakan bahwa pembelajaraan perbaikan itu berfungsi sebagai pengobatan (terapis) untuk penyembuhan, yang disembuhkan adalah beberapa

hambatan (gangguan) kepribadian yang berkaitan dengan kesulitan belajar sehingga dapat timbal balik dalam arti perbaikan belajar juga perbaikan pribadi dan sebaliknya.

Remedial Teaching berasal dari kata Remedy (Inggris) yang artinya menyembuhkan. Istilah pembelajaraan remedial pada mulanya adalah kegiatan mengajar untuk anak luar biasa yang mengalami berbagai hambatan (sakit). Namaun, dewasa ini pengertian ini sudah berkembang seperti uraian tersebut di atas, sehingga anak yang normal pun memerlukan pelayanan pembelajaraan remedial (Remedial Teaching).

2. Tujuan Pembelajaran Remedial

Secara umum tujuan pembelajaraan perbaikan tidak berbeda dengan pembelajaraan biasa yaitu dalam mencapai tujuan belajar yang telah ditetapkan. Secara khusus pembelajaraan perbaikan bertujuan agar siswa yang mengalami 
kesulitan belajar dapat mencapai prestasi belajar yang diharapkan sekolah melalui proses perbaikan. Secara terperinci tujuan pembelajaraan perbaikan adalah :

(a)Agar siswa dapat memahami dirinya khususnya prestasi belajarnya

(b)Dapat memperbaiki atau mengubah cara belajarnya ke arah yang lebih baik (c) Dapat memilih mater dan fasilitas belajar secara cepat (d) Dapat mengembangkan sikap dan kebiasaan yang dapat mendorong tercapai hasil yang lebih baik (e) Dapat melaksanakan tugas-tugas belajar yang diberikan kepadanya.

\section{Fungsi Remedial}

Pembelajaraan remedial merupakan bagian terpenting dari keselururhan proses pemebelajaran mempunyai banyak fungsi dalam membeantu peserta didik yang megalami kesulitan belajar, antara lain :

(a)Fungsi korektif, adalah usaha untuk memperbaiki atau meninjau kembali sesuatu yang dianggap keliru

(b)Fungsi pemahaman, dalam pembelajaraan remedial terjadi proses pemahaman terhadap pribadi peserta didik, baik dari pihak guru, pembibmbing maupun peserta didik itu sendiri.

(c)Fungsi penyesuaian, dalam pembelajaraan remedial peserta didik dibantu untuk belajar sesuai dengan keadaan dan kemampuan yang dimiliki sehingga tidak mrupakan beban bagi peserta didik.

(d)Fungsi pengayaan, dalam pembelajaraan remedial guru berusaha membantu peserta didik mengatasi kesulitan belajar dengan menyediakan atau menambah berbagai materi pegajaran yang tidak atau belum disampaikan dalam pembelajaraan biasa.

(e)Fungsi akselerasi, dalam pembelajaraan guru berusaha mempercepat pembelajaraan dengan menambah frekuensi pertemuan dan materi pembelajaraan.

(f)Fungsi terapeutik, pembelajaraan remedial mengandung unsusr terapeutik karena secara langsung atau tidak langsung berusaha menyembuhkan beberapa gangguan atau hambatan peserta didik.

1. Perbedaan Remedial dengan Proses Belajar Mengajar Biasa

Pembelajaraan perbaikan pada hakekatnya sama dengan proses belajar mengajar biasa namun berbeda dalam dua hal berikut, yaitu :

a. Tujuannya lebih diarahkan pada peningkatan prestasi, baik kualitas maupun kuantitas dari prestasi yang telah dicapai pada proses belajar mengajar sebelumnya, sehingga sekurang-kurangnya dapat memenuhi kriteria keberhasilan minimal yang dipersyaratkan. 
b. Strategi pendekatan (metode, program, jenis tugas) lebih menekankan penyesuaian tehadap keragaman kondisi objektif siswa yang dapat dipandang sebagai modifikasi dari pemebelajaran biasa.

Depdiknas, (Jakarta, 2004:19) Atas perbedaan tersebut pembelajaraan remedial didefiniskan sebagai upaya guru untuk menciptakan situasi yang memungkinkan individu atau kelompok siswa lebih mampu mengembangkan dirinya seoptimal mungkin, sehingga dapat memenuhi kriteria keberhasilan minimal yang disyaratkan.

Menurut Mulyasa (2003 : 99) sekolah perlu memberikan perlakuan khusus terhadap peserta didik yang mendapat kesulitan belajar melalui kegiatan remedial, peserta didik yang cemerlang diberikan kesempatan untuk tetap mempertahankan kecepatan belajarnya melalui kegiatan pengayaan. kedua program itu dilakukan oleh sekolah karena lebih mengetahui dan memahami kemajuan belajar setiap peserta didik.

Menurut Arikunto, ( 2006 : 180) Remedial adalah kegiatan yang diberikan kepada siswa-siswa yang belum menguasai bahan pelajaran yang ada diberikan oleh guru, dengan maksud memprtinggi tingkat penguasaan terhadap bahan ajaran tersebut.

Dasar pelaksanaan remadal adalah dari hasil analisis atau doagnosis terhadap proses belajar mengajar atau standar ketuntasan belajar minimal yang telah ditetapkan.

Target khusus pembelajaraan remedial adalah siswa-siswi yang diidentifikasi sebagai siswa yang belum tuntas pada suatu kompetensi dasar, atau beberapa kompetensi dasar pada suatu pembelajaran.

Remedial bertolak pada konsep belajar tntas, yang ditandai dengan system belajar menggunakan modul. Pada tiap akhir kegiatan pembelajaran, guru melakuakn evaluasi formatif, dan setelah adanya evaluasi formatif itulah anak-anak yang belum menguasai bahan pelajaran diberikan pembelajaraan remedial, agar tujuan belajar yang telah ditetapkan sebelumnya dicapai.

Mulyono,(2003:20) Tugas untuk memberikan pembelajaraan remedial bagi anak-anak berkesulitan belajar yang berta seperti itu sebaiknya diserahka kepada guru yang memiliki keahlian khusus dalam pelayanan penddikan bagi anak-anak berkesulita belajar. Guru yang harus memberikan pelayanan pembelajaraan perbaikan bagi anak berkesulitan belajar disebur guru remedial (Remedial Teacher).

Dengan demikian disuatu sekolah idealnya ada dua jeis guru bidang studi dan guru remedial yang khusus memberikan pelayanan remedial bagi anak-anak berkesulitan belajar.

2. Langkah-langkah dan Model Pembelajaran Remedial

Sebelum pembelajaraan remedial diberikan, guru terlebih dahulu perlu mengakkan diagnosis kesulitan belajar, yaitu menentukan jenis dan penyebab kesulitan serta alternative strategi pembelajaraan remedial yang efektif dan efisisen. ada enam langkah prosedur diagnosis yang perlu dilalui, yaitu : 

a. Identifikasi
b. Lokalisasi letak kesulitan
c. Lokalisasi penyebab kesulitan
d. Memperkirakan kemungkinan bantuan
e. Menetapkan kemungkinan cara mengatasi kesulitan
f. Tindak lanjut

Ada tiga model pemebelajaran remedial, yaitu :

1. Pembelajaran remedial di luar jam sekolah (outside school hours)

Pada model ini pemberian pembelajaran remedial dilakukan secara kelompok (klasikal), diluar jam pembelajaran utama. Artinya sekolah megalokasikan jam khusus untuk remedial, caranya siswa yang memiliki kesulitan belajar, sering dapat prestasi kurang, atau siapa saja yang mau mengulang materi tertentu di smaping, diorganisasikan kedalam kelas khusus.

Model ini lebih tepat guna bila kasusnya bersifat kelompok (sebagian besar siswa tidak mencapai ketuntasan). Metode mengajar pada model ini harus lebih menekankan pada penguasaan materi.

2. Pembelajaran remedial pemisahan (withdrawal)

Pembelajaran remedial model ini dilakukan dengan cara memisahkan siswa dari kelas regularkedalam kelas remedial. Pemisahan ini bertujuan untuk memberikan pengetahuan dasar tentag materi yang belum dikuasainya. Model ini tepat digunakan bila kasusnya bersifat individual. Materi pemebelajaran lebih ditekankan pada materi esensial (merupakan dasar bagi topik atau materi lain, terkait dengan pelajaran lain, atau sangat berguna bagi kehidupan).

\section{Pembelajaran remedial tim}

Untuk dapat melakukan model ini diperlukan tim atau sejumlah guru dari mata pelajaran sejenis (misalnya guru matematika), mereka berkumpul sepakat secara bersama-sama memebrikan bantuan remedial. Teknis pembelajaran bisa dilakukan secara individual atau klasikal.

Ischak S.W. (2003:42), bentuk-bentuk lain remedial yaitu :

1. Mengajarkan kembali (re-teaching)

Maksudnya adalah kegiatan perbaikan dilaksanakan dengan jalan mengajarkan kembali bahan ynag sama kepada para siswa yang memerlukan bantuan dengan cara menyajikan yang berbeda dalm hal-hal sebagai berikut :

a. Kegiatan belajar mengajar dalam situasi kelompok yang telah dilakukan

b. Melibatkan siswa dalam kegiatan belajar mengajar 
c. Memberikan dorongan (motivasi) atau penggalakan kepada siswa pada kegiatan belajar

2. Bimbingan individu atau kelompok

3. Memberikan pekerjaan rumah

4. Menyuruh siswa mempelajari bahan yang sama dari buku-buku pelajaran, buku paket atau sumber-sumber bacaan yang lain.

Slameto, (1999 :79). Secara garis besar pembelajaraan remedial atau remedial teaching adalah suatu usaha untuk membantu siswa mengatasi kesulitan dalam penguasaan bahan pelajaran tertentu yang tidak dapat diatasi dalam pelajaran klasikal. Pelaksanaan pelajaran remedial mengikuti langkah-langkah sebagai berikut :

a. Menandai siswa yang memiliki kelemahan dalam pelajaran tertentu

b. Mentrasir (meneliti kebelakang) tentang prestasi/nilai siswa tersebut pada kurtal/semester tahun-tahun sebelumnya. Hal ini dimaksud untuk mengetahui sejak kapan kelemahan tersebut dapat dialami.

c. Mencari sebab-sebab atau latar belakang kelemahan belajar siswa diluar jam pelajaran, mungkin sebab-sebab ini berasal dari keluarga, lingkungan, sekolah, temantemannya, perlengkapan belajar dan lain-lain. Atau bisa juga bersumber pada hal-hal yang ada pada siswa itu sendiri.

d. Diberikan pertanyaan-pertanyaan atau soal-soal dari bahan pelajarn yang disediakan untuk kurtal/semester tersebut (kurtal/semester dimana siswa diduga mulai menghadapi kesulitan dalam pelajaran tersebut). Ruang lingkup bahan diambil di kurikulim ( garis-garis besar program pembelajaraan), sedangkan bahannya dari buku teks pelajaran.

e. Bila hasil dari langkah tersebut (langkah dnegan) ternyata siswa itu hanya menguasai sebagian kecil dari bahan tersebut, maka dicoba di beri soal lagi dari bahan kuartal/semester yang lebih lalu lagi.

f. Setelah diketahui kelemahan-kelemahan penguasaan materi siswa dalam satuan bahan pada kuartal tersebut, maka mulailah dengan bantuan pelajarannya.

B. Metode pelaksanaan penegajaran remedial

Senada dengan pendapat diatas, arikunto juga mengemukakanbetuk-bentuk kegiatan remedial antara lain :

a. Metode pemberian tugas dan resitasi yaitu melaksanakan tugas yang diberikan oleh guru dan melaporkan hasilnya.

b. Metode diskusi

c. Metode pendekatan proses

d. Metode penemuan

e. Metode kerja kelompok

f. Metode eksperimen 
g. Metode tanya jawab

Dalam pembelajaraan remedial juga terdapat bebrapa metode. Metode pembelajaraan remedial merupakan metode yang dilaksanakan dalam keseluruhan kegiatan bimbingan kesulitan belajar mulai dari langkah identifikasi kasus sampai dengan langkah tindak lanjut. Metode yang digunakan dalam pembelajaraan remedial yaitu :

1. Metode pemberian tugas Metode ini dilaksanakan dengan cara memberi tugas atau kegiatan yang harus dilakuakan oleh peserta didik yang mengalami kesuliatan belajar. Jenis dan sifat tugas harus sesuai dengan jenis, sifat dan latar belakang kesulitan belajar yang dihadapi peserta didik.

2. Metode diskusi Diskusi adalah suatu bentuk interaksi antar individu atau kelompok untuk membahas suatu masalah. Diskusi digunakan dlama pembelajaraan remedial untuk memperbaiki kesulitan belajar dengan memanfaatkan interaksi individu dalam kelompok.

3. Metode tanya-jawab Tanya jawab dalam pembelajaraan remedial dilakukan dalam bentuk dialog antara guru dengan peserta didik yang mengalami kesulitan belajar. Tanya jawab dilakukan secara kelompok dengan peserta didik.

4. Metode kerja kelompok Kerja kelompok dalam pembelajaraan remedial diusahakan agar terjadi interaksi diantara anggota dalam kelompok. Kelompok sebaiknya heterogen artinya dalam satu kelompok terdiri dari pria dan wanita, peserta didik yang mengalami kesulitan belajar dan peserta didik yang tidak mengalami kesulitan belajar. Metode ini dapat meningkatkan pemahaman diri masing-masing anggota, minat belajar dan rasa tanggung jawa peserta didik.

5. Metode tutor sebaya

Tutor sebaya ialah peserta didik ditunjuk untuk membantu teman-temannya atau peserta didik lainnya yang mengalami keuslitan belajar. Hal-hal yang perlu dipertimbangkan dalam menentukan tutor sebaya adalah :

a. Mendapat persetujuan dari peserta didik yang mengikuti program perbaikan.

b. Mempunyai prestasi akdemik yang baik, kreatif, dan dapat menerangkan bahan yang dibutuhkan oleh peserta didik yang mengikuti program perbaikan.

c. Tidak sombong, sabar, telaten, hubungan sosialnya bagus, tidak pelit, dan suka menolong sesam teman.

6. Metode pembelajaraan individual Pembelajaraan individual dalam pembelajaraan remedial yaitu proses pembelajaran yang hanya melibatkan seorang guru dan seorang peserta didik yang mengalami kesulitan belajar. Metode ini dangat intensif karena pelayanan yang diberikan disesuaika dengan 
kesulitan dan kemampuan peserta didik. Pembelajaraan individual bersifat penyembuhan artinya memperbaiki cara belajar, dengan mengulang bahan pelajaran yang telah diberikan atau latihan mengerjakan soal atau mungkin memberikan materi baru.

Secara umum pembelajaraan remedial bertujuan membantu siswa mencapai hasil belajar sesuai dengan tujuan pembelajaraan yang telah ditetapkan dalam kurikulum. Secara khusus, pembelajaraan remedial bertujuan membantu siswa yang mengalami kesuliatan belajar agar mencapai prestasi yang diharapkan melalui proses penyembuhan dalam aspek kepribadian atau dalam proses belajar mengajar.

1. Pendekatan-pendekatan dalam pembelajaraan remedial

Terdapat pendekatan-pendekatan dalam pembelajaraan remedial, antara lain :

1. Pendekatan kuratif dalam pembelajaraan remedial

Pendekatan ini dilakukan setelah program pembelajaran yang poko selesai dilaksanakan dan dievaluasi guru akan menjumpai beberapa bagian dari peserta didik yang tidak mampu menguasai seluruh bahan yang disampaikan. Pelaksanaan pendekatan kuratif dapat dilakukan dengan cara :

a. Pengulangan (repetation), dapat dilakukan setiap akhir jam pertemuan, akhir unit pelajaran atau setiap pokok bahasan. Sedangkan pelaksanaannya dapat secara :

1. Individual kalau ternyata yang mengalami kesulitan terbatas.

2. Kelompok kalau ternyata sejumlah siswa dalam bidang studi tertentu mempunyai jenis/sifat kesalahan atau kesulitan bersama. Dan waktu dan cara pelaksanaannya :

a. Bila sebagian/seluruh kelas mengalami kesulitan sama, diadakan pertemuan kelas biasa, berikutnya bahan dipresentasekan kembali, diadakan latihan/penguasaan/soal bentuk sejenis, kemudian diadakan pengukuran kembali untuk mendeteksi hasil pengikatan kearah kriteria keberhasilan.

b. Diadakan diluar jam pertemua biasa, diadakan jam pelajaran tambahan bila yang mengalami kesulitan hanya sejumlah orang tertentu (waktu sore, waktu istirahat, dan sebagainya), diberikan pekerjaan rumah dan dikoreksi oleh guru itu sendiri.

c. Diadakan kelas remedial (kelas khusus) bagi siswa yang mengalami kesulitan khusus dengan bimbingan khusus diadakan pengulangan secara total kalau ternyata jauh dibawah kriteria keberhasilan minimal.

b. Pengayaan dan pengukuhan (enrichment dan reinforcement) 
Layanan pengayaan dapat ditujukan kepada peserta didik yang mempunyai kelemahan ringan dan secara akademik mungkin peserta didik tersebut cerdas. Dapat dilakukan dengan memberikan pekerjaan rumah atau pekerjaan dikelas pada saat pelajaran berlangsung.

c. Percepatan (acceleration)

Layanan percepatan ini diberikan kepada peserta didik yang berbakat namun menunjukkan kesulitan psikososial.

2. Pendekatan preventif dalam pembelajaraan remedial

Pendekatan preventif diberikan kepada peserta didik yang diduga akan mengalami kesulitan dalam menyelesaikan program yang akan ditempuh. Guru mengklasifikasikan kemampuan siswa didik menjadi tiga golongan, yaitu peserta didik yang mampu menyelesaikan program sesuai waktu yang ditentukan, peserta didik yang diperkirakan akan mampu menyelesaikan program lebih cepat dari waktu yang ditentukan, dan peserta didik yang tidak dapat menyelesaikan program sesuai waktu yang ditentukan. Sesuai penggolongan tersebut maka teknik pelayanan yang dapat dilakukan adalah sebagai berikut:

a. Kelompok belajar homogen, dalam kelompok ini peserta didik diberi pelajaran, waktu dan tes yang sama.

b. Kelompok individual, pembelajaraan disesuaikan dengan keadaan peserta didik, sehingga setiap peserta didik mempunyai program tersendiri.

c. Layanan pembelajaraan dengan kelas khusus, peserta didik mengikuti program pembelajaran yang sama dalam satu kelas. Peserta yang mengalami kesulitan dalam bidang tertentu disediakan kelas khusus remedial. Bagi yang cepat belajarnya disediakan program pengayaan.

3. Pendekatan pengembangan dalam pembelajaraan remedial

Pembelajaraan remedial yang bersifat pengembangan merupakan upaya diagnostik yang dilakukan guru selama berlangsungnya pembelajaran. Sasarannya agara peserta didik dapat segera mengatasi hambatan-hambatan yang dialami selama mengikuti pembelajaran.

Dalam pembelajaraan remedial juga terdapat beberapa metode. Metode pembelajaraan remedial merupakan metode yang dilaksanakan dalam keseluruhan kegiatan bimbingan kesulitan belajar mulai dari langkah identifikasi sampai dengan langkah tindak lanjut.

2. Prosedur pelaksanaan Pembelajaraan Remedial

Remedial teaching yang merupakan salah satu bentuk bimbingan belajar dapat dilaksankan melalui prosedur sebagai berikut 
a. Meneliti kasus dengan permasalahan sebagai titik tolak kegiatan-kegiatan berikutnya. Tujuan penelitian kembali kasus ini adalah memperoleh gambaran ynag jelas mengenai kasus tersebut, serta cara dan kemungkinan pemecahannya. Berdasarkan atas penelitian kasus akan dapat ditentukan peserta didik yang perlu mendapat remedial teaching. Kemudian ditentukan besarnya kelemahan yang dialami dan dalam bidang studi apa saja yang mengalami kelemahan. Selanjutnya meneliti dalam domain apa mengalami kesulitan apakah kognitifnya seperti hafalan, pemahaman ataukah aplikasinya, ataukah psikomotornya seperti keterampilan, kemampuan ekspresinya dan lain-lain.

Dalam langkah pertama ini juga dibahas mengenai faktor-faktor penyebab kesulitan peserta didik, baik yang berasal dari diri sendiri maupun yang berasal dari luar dirinya. Yang berasal dari dalam dirinya seperti tingkat kecerdasannya, motivasi untuk berprestasi, sikap dalam belajar, kebiasaan belajar, penguasaan pengetahuan dasar. Sedangkan penyebab yang berasal dari luar misalnya keterbatasan sumber belajar, kecocokannya dengan program yang diambil kurang tepat cara mengajar fasilitas yang terbatas, dan lain-lain.

b. Menentukan tindakan yang harus dilakukan. Dalam langkah ini sebagai kelanjutan langkah pertama diatas dilakukan usaha-usaha untuk menentukan karakteristik kasusu yang ditangani tersebut.

Kasus yang ringan bila peserta didik belum menenmukan cara belajar yang baik. Kasus yang berat adalah disamping belum memiliki cara belajar yang baik juga memiliki hambatan emosional. Setelah karakteristik harus ditentukan, maka tindakan pemecahan perlu dipikirkan yaitu :

1. Kalau kasusnya ringan, Tindakan yang ditentukan adalah member remedial teaching

2. Kalau kasusnya cukup berat, maka sebelum diberikan remedial teaching harus diberi layanan konseling lebih dahulu, yaitu untuk mengatasi hambatanhambatan emosional yang mempengaruhi cara belajarnya.

Berdasarkan atas karakteristik kasus tersebut, maka pada tahap kedua ini adalah membuat keputusan tentang cara mana yang harus dipilih diantara a dan b diatas. Untuk itu beberapa pertimbangan yang dapat dipakai dalam mengambil keputusan adalah faktor efektifitas, efesiensi, faktor kesulitan dengan jenis masalah. 
c. Pemberian layanan kasus yaitu bimbingan dan konseling. Tujuan dari layanan kasus bimbingan enyuluhan ini adalah mengusahakan agar peserta didik yang menjadi kasus ini terbatas adri hambatan mental emosional (ketegangan batin), sehingga kemudian siap menghadapi kegiatan belajar secara wajar. Dalam hal ini dapat dilakukan oleh petugas-petugas BP atau psikologi ataupun konselor yang ahli dalam bidangnya. Atau dapat juga bentuk konseling disini adalah psikoterapi yang dilakukan oleh ahlinya. Tetapi ada kalanya kasus ini dapat dilakukan oleh guru sendiri bila masalah yang dihadapi adalah :

1. kasus yang mempunyai latar belakang kurang motivasi dan minat belajar. Dalam hal ini cara yang ditempuh adalah antara lain menghindari anak dari pernyataan-pernyataan negatif yang dapat melemahkan semangat belajar, menciptakan suasana kompetitif yang sehat, memberikan dorongan agar lebih berhasil dalam belajar pada waktu-waktu berikutnya, dan lain-lain.

2. Kasus yang mempunyai latar belakang sikap negatif terhadap guru. Untuk ini langkah yang dapat dilakukan adalah menciptakan hubungan yang hangat antara guru dan peserta didik dan peserta didik dengan peserta didik, menciptakan iklim sosial yang sehat dalam kelas, memberikan pengalaman yang menyenangkan.

3. Kasus yang mempunyai latar belakngketidak cocokan antara keadaan pribasi dengan lingkungan dan programnya. Untuk itu dapat diberikan saran yaitu memberi bimbingan informasi dalam memilih progra dan cara belajar, pengenalan dengan memberi wawasan tentang program yang ditempuh.

\section{Hasil Belajar}

Ahli psikologi dan pendidikan mengemukakan rumusan yang berlainan sesuai dengan bidang keahlian mereka masing-masing. Tentu saja mereka mempunyai alasan yang dapat dipertanggung jawabkan secara ilmiah. Untuk lebih jelasnya akan dikemukakan beberapa pendapat para ahli mengenai definisi belajar.

Slameto, (2003: 2), dalam pendapatnya mendefinisikan bahwa belajar adalah suatu usaha yang dilakukan seseorang untuk memperoleh suatu perubahan tingkah laku yang baru secara keseluruhan, sebagai hasil pengalamnnya sendiri dalam interaksi dengan lingkungannya.

Dimyati dan Mudjiono,(2002 : 32 )Dalam kegiatan belajar terjadi perubahan perilaku, sebagaimana dikemukakan oleh dimyanti bahwa belajar merupakan suatu proses internal yang kompleks, yang terlibat dalam proses internal tersebut 
adalah yang meliputi unsur afektif, dalam materi afektif berkaitan dengan sikap, nilai-nilai, interes, apresiasi, dan penyesuaian perasaan sosial.

Dari definisi tersebut, dapat digambarkan bahwa belajar merupakn segenap rangkaian kegiatan atau aktivitas yang dilakukan secara sadar oleh individu dan mengakibatkan perubahan dalam dirinya berupa penambahan pengetahuan melalui alat indera dan pengalamannya serta terjadi perubahan tingkah laku.

Setelah proses pemeblajaran berlangsung, seorang guru atau pendidik ingin mengetahui sejauh mana kemampuan siswa menyerap materi pelajaran yang dosampaikannya. Adakalanya kemampuan siswa tersebut tinggi, sedang ataupun rendah. Kemampuan siswa dalam menyerap materi pelajaran dikenal dengan hasil belajar.

Dimyati dan mudjiono mengatakan :Hasil belajar adalah hasil dari suatu interaksi tindak belajar dan tindak mengajar. Dari sisi guru, tindak mengajar diakhiri dengan proses evaluasi belajar. Dari siswa, hasil belajar merupakan berakhirnya batas dan puncak belajar. Hasil belajar, untuk sebagian adalah berkat tindak guru, suatu pencapaian atau (proses,cara, perbuatan mencapai) tujuan pembelajaraan). Pada bagian lain merupakan peningkatan kemampuan mental siswa. Hasil belajar tersebut dibedakan menjadi damapk pembelajaraan dan dampak pengiring. Dampak pembelajaraan adalah hasil dapat diukur, seperti tertuang dalam angka rapor dan dampak pengiring adalah terapan pengetahuan dan kemampuan dibidang lain, suatu transfer belajar.

Nana sudjanamengemukakan unsur-unsur yang terdapat dalam ketiga aspek hasil belajar, yakni :

1. Hasil belajar bidang koginitif

a. Tipe hasil pengetahuan hafalan (knowledge)

b. Tipe hasil belajar pemahaman (comperhention)

c. Tipe hasil belajar penerapan (applicatio)

d. Tipe hasil belajar analisis

e. Tipe hasil belajar sintesis

f. Tipe hasil belajar evaluasi

2. Hasil bidang afektif

Bidang afektif berkenaan dngan sikap dan nilai. Beberapa ahli mengatakan bahwa sikap seseorang dapat diramalkan perubahannya, bila seseorang telah menguasai bidang kognitif tingkat tinggi. Hasil belajar bidang afektif kurang mendapat perhatian dari guru. Para guru lebih banyak memeberi tekanan pada bidang kognitif semata-mata, tipe hasil belajar afektif tampak pada siswa daalm berbagai tingkah laku seperti perhatian terhadap pelajaran, disiplin, motivasi belajar, menghargai guru dan teman sekelas, kebiasaan belajar, dan lain-lain. 
3. Hasil belajar psikomotorik

Hasil belajar bidang psikomotorik tampak dalam bentuk keterampilan (Skill) ,kemampuan bertindak individu (seseorang). Seseorang yang telah menguasai tingkat kognitif maka perilaku orang tersebut sudah diramalkan carlRogers.

Hartono, ( 2000 : 1), Dalam tulisannya, hartono mengemukakan bahwa belajar merupakan usaha indidvidu untuk memperoleh perubahan tingkah laku secara keseluruhan. Perubahan yang dimaksud adalah perubahan pada aspek pengetahuan, sikap dan keterampilan. Sedangkan ciri-ciri perubahan yang terjadi dari belajar seperti :

1. Perubahan terjadi secara sadar

2. Bersifat kontiniu dan fungsional

3. Berdifat positif dan aktif

4. Bersifat permanen

5. Perubahan terjadi secara terarah dan bertujuan

6. Mencakup seluruh aspek tingkah laku.

Faktor-faktor yangmempengaruhi hasil belajar secara garis besar dipengaruhi oleh dua faktor, yaitu faktor dari dalam diri seseorang dan faktor luar (lingkungan sosial). Tulus Tu'u mengemukakan bahwa faktor-faktor yang mempengaruhi prestasi belajar antara lain

\section{a. kecerdasan}

Bahwa tinggi rendahnya kecerdasan yang dimiliki seorang siswa sangat menentukan keberhasilannya mencapai prestasi belajar, termasuk prestasiprestasi lain sesuai macam kecerdasan yang menonjol yang ada dalam dirinya.

b. Bakat

Bakat diartika sebagai kemampuan yang ada pada seseorang yang dibawa sejak lahir, yang diterima sebagai warisan dari orang tuanya.

c. Minta dan perhatian

Minat adalah kecenderungan yang besar terhadap sesuatu. Perhatian adalah melihat, mendengar dengan baik dan teliti terhadap sesuatu.Minat dan perhatian biasanya berkaitan erat. Minat dan perhatian yang tinggi pada suatu materi akan memberikan dampak yang baik bagi prestasi belajarnya.

d. Motif adalahdorongan yang membuat seorang berbuat sesuatu. Motif selalu mendasari dan mempengaruhi setiap usaha serta kegiatan sesesorang untuk mencapai tujuan yang diinginkannya. Dalam belajar, jika siswa mempunyai motifasi 
yang baik dan kuat, hal itu akan memperbesar usaha dan kegiatannya mencapai prestasi yang tinggi.

e. Cara Belajar

Keberhasilan studi siswa di pengerahui pula oleh cara belajaranya . Cara belajar yang efisien memungkingkan siswa mencapai prestasi yang tinggi dibandingkan dengan cara belajar yang tidak efisien. Cara belajar yang efisien sebagai berikut :

1. Berkonsentrasi sebelum dan pada saat belajar

2. Segera mempelajari kembali bahan yang telah di terima

3. Membaca dengan teliti dan baikbahan yang sedang di pelajari,dan berusaha mengusai sebaik- baiknya

4. Mencoba menyelesaikan dan melatih mengerjakan soal -soal

f. Lingkungan keluarga

Keluarga merupakan salah satu potensi yang besar dan dan positif dalam

pengaruh pada prestasi siswa

g. Sekolah

Selain keluarga, sekolah adalah lingkungan kedua yang berperang besar mempengaruhi pada prestasi belajar siswa.

\section{Pembelajaran Matematika}

a. Pengertian Matematika

Matematika merupakan ilmu dasar yang sudah menjadi alat untuk mempelajari ilmu-ilmu lain (Prihandoko, 2006). Oleh karena itu penguasaan terhadap Matematika mutlak diperlukan dan konsep-konsep Matematika harus dipahami dengan betul dan benar sejak dini. Belajar Matematika adalah belajar tentang konsep-konsep dan struktur-struktur Matematika yang terdapat dalam materi yang dipelajari serta memberi hubungan antara konsep-konsep dan struktur-struktur Matematika (Bruner dalam Prihandoko, 2006).

Soedjadi (2000: 11) menyajikan beberapa definisi dari matematika sebagai berikut ini:

1) Matematika adalah cabang ilmu pengetahuan eksak dan terorganisir secara sistematik.

2) Matematika adalah pengetahuan tentang bilangan dan kalkulasi.

3) Matematika adalah pengetahuan tentang penalaran logik dan berhubungan dengan bilangan.

4) Matematika adalah pengetahuan tentang fakta-fakta kuantitatif dan masalah tentang ruang dan bentuk. 
5) Matematika adalah pengetahuan tentang struktur-struktur yang logik.

6) Matematika adalah pengetahuan tentang aturanaturan yang ketat.

Pada pembelajaran matematika harus terkait antara pengalaman belajar sebelum dengan konsep yang akan diajarkan. Berdasarkan dimensi keterkaitan antara konsep dalam teori belajar menurut Ausubel (dalam Heruman, 2007:4) bahwa setiap konsep dalam matematika saling keterkaitan antara satu dengan yang lain.

Secara umum terdapat tiga tahapan pembelajaran matematika (Heruman, 2007:2) yaitu :

a) Penanaman konsep dasar Yaitu pembelajaran suatu konsep baru matematika ketika siswa belum perrnah mempelajari konsep tersebut;

b) Pemahaman konsep Yaitu pembelajaran lanjutan dari penanaman konsep yang bertujuan agar siswa lebih memahamisuatu konsep matematika.

c) Pembinaan keterampilan, yaitu pembelajaran lanjutan dari penanaman konsep dan pemahamankonsep. Pembelajaran pembinaan keterampilan bertujuan agar siswa lebih trampil dalam menggunakan berbagai konsep matematika. Seperti halnya penanaman konsep, pembinaan keterampilan juga terdapat dua pengertian. Pertama, merupakan kelanjutan dari penanaman pembelajaran konsep dan pemahaman konsep dalam satu pertemuan. Kedua, pembelajaran pembinaan keterampilan dilakukan pada pertemuan yang berbeda tapi masih merupakan kelanjutan dari penanaman dan pemahaman konsep.

b. Tujuan Pembelajaran Matematika

Pembelajaran matematika di Sekolah Dasar sebagai bagian dari sistem pendidikan nasional. Pembelajaran matematika pada tingkat SD memiliki tujuan-tujuan yang ingin dicapai. Karso (2004: 1.5) mengemukakan bahwa matematika bagi siswa SD bertujuan untuk kepentingan hidup dalam lingkungannya, untuk mengembangkan pola pikirnya, dan untuk mempelajari ilmu-ilmu yang kemudian. Kegunaan atau manfaat matematika bagi siswa SD adalah sesuatu yang jelas yang tidak perlu dipersoalkan lagi, lebih-lebih pada era pengembangan ilmu pengetahuan dan teknologi sekarang ini. Soedjadi (2000: 45) membagi tujuan matematika menjadi dua yaitu,

1) Tujuan yang bersifat formal yang lebih menekankan pada penalaran dan membentuk sikap; dan

2) Tujuan yang bersifat material yang menekankan kepada menata penalaran dan membentuk kepribadian.

Tujuan tersebut menjadi acuan dalam pembelajaran matematika. Tujuan mata pelajaran matematika tingkat SD/MI tersebut tidak hanya terpusat pada aspek kognitif saja, namun juga aspek afektif dan psikomotor. Sedangkan untuk jangka panjang tujuan matematika adalah untuk mengaplikasikan matematika dalam 
kehidupan sehari-hari. Dengan adanya tujuan pembelajaran matematika, maka unsur dalam pembelajaran yaitu meliputi guru dan siswa diharapkan bisa mengoptimalisasikan pembelajaran matematika untuk mencapai tujuan tersebut.

c. Karakteristik Pembelajaran Matematika

Matematika memiliki ciri-ciri atau sifat khas yang membedakan dengan ilmu-ilmu lain. Frans Susilo dalam Supatmono (2009: 8) menyatakan ciri-ciri matematika adalah sebagai berikut.

a) Matematika bukanlah ilmu yang memiliki kebenaran mutlak. Kebenaran dalam matematika adalah kebenaran nisbi yang tergantung pada kesepakatan yang disetujui bersama.

b) Matematika bukanlah ilmu yang tidak bisa salah. Sebagai ilmu yang dibentuk dan dikembangkan oleh manusia, tentu matematika tidak lepas dari kesalahan dan keterbatasan. Meskipun demikian, melalui kesalahan-kesalahan itulah matematika didorong dan dipacu untuk terus tumbuh dan berkembang.

c) Matematika bukanlah kumpulan angka, simbol, dan rumus yang tidak ada kaitannya dengan dunia nyata. Justru sebaliknya, matematika tumbuh dan berakar dari dunia nyata.

d) Matematika bukanlah kumpulan teknik pengerjaan yang hanya perlu dihapal saja sehingga siap pakai untuk menyelesaikan soal-soal. Dalam matematika, keindahan bukan semata-mata hanya ditentukan dari hasil akhir tetapi justru dari latar belakang dan proses yang mengantar sampai terjadinya hasil akhir tersebut.

e) Objek matematika adalah unsur-unsur yang bersifat sosiakultural- historis, yaitu merupakan milik bersama seluruh umat manusia, sebagai salah satu sarana yang dipergunakan manusia untuk mengembangkan segi-segi tertentu dalam perikehidupan manusiawinya, dan yang terbentuk melalui proses panjang menyejarah yang membentuk wajah matematika itu sendiri.

Dari uraian tentang ciri-ciri matematika tersebut, disebutkan bahwa kehadiran matematika adalah berasal dari masalah di dunia nyata dan sebagai sarana yang dipergunakan manusia untuk menyelesaikan permasalahan tersebut.

\section{B. Kerangka Berpikir}

Berdasarkan latar belakang dan kajian teori yang telah dikemukakan, bahwa proses belajar dengan penggunaan Remedial lansung pada hasil belajar dengan memperhatikan gaya dan cara belajar peserta didik, namun disisi lain tidak dipungkiri bahwa dalam pelaksanaannya terkadang ada faktor lain yang turut mempengaruhi. 
Pembelajaran Matematika yang sebagian peserta didik masih menganggapnya membosankan atau kurang menarik, tentu membutuhkan sikap guru dalam mengatasi kejenuhan tersebut. Salah satu alternative yang dapat mengoptimalkan hasil belajar peserta didik dalam pelajaran Matematika yaitu dengan menggunakan Remedial lansung. Dengan penggunaan remedial lansung diharapkan dapat memberikan wawasan dan pemahaman yang mendalam kepada peserta didik

Penggunaan Remedial lansung dipilih karena masalah yang biasa dialami peserta didik, ini diketahui berdasarkan hasil belajar siswa yang telah dilakukan dimana terlihat guru dan siswa melakukan proses belajar mengajar setelah melakukan proses pembelajaran dapat di ketahui bahwa terdapat beberapa siswa yang tidak mencapai kriteria ketuntasan maka guru melakukan perbaikan yaitu remedial setelah melakukan remedia maka dapat di simpulkan hasil belajar matematika meningkat

Selain itu guru juga belum mencoba menggunakan remedia lansung yang dapat mengaktifkan peserta didik. Untuk memperbaikinya, maka peneliti berkonsultasi dengan guru wali kelas dengan menggunakan remedial lansung yang dianggap mampu mengatasi masalah yang dialami peserta didik dalam pembelajaran matematika, diharapkan peserta didik aktif, dan tertarik dalam mengikuti proses pembelajaran sehingga akan berpengaruh pada hasil belajar peserta didik.

Berdasarkan uraian di atas maka penulis melakukan penelitian untuk mengetahui terdapat atau tidaknya pengaruh penggunaan Remedial lansung terhadap hasil belajar peserta didik dalam Pengaruh Remedial Lansung terhadap Hasil belajar siswa pembelajaran Matematika di kelas V SD Negeri Sikapa Kab.barru.

Pembelajaran Matematika

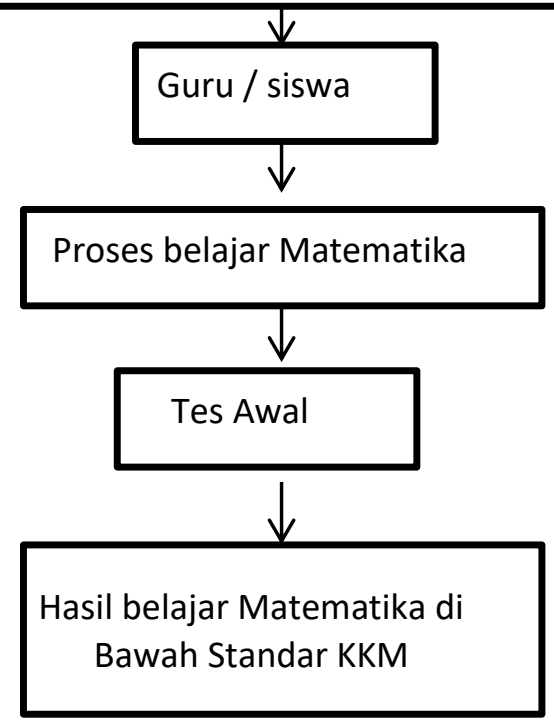




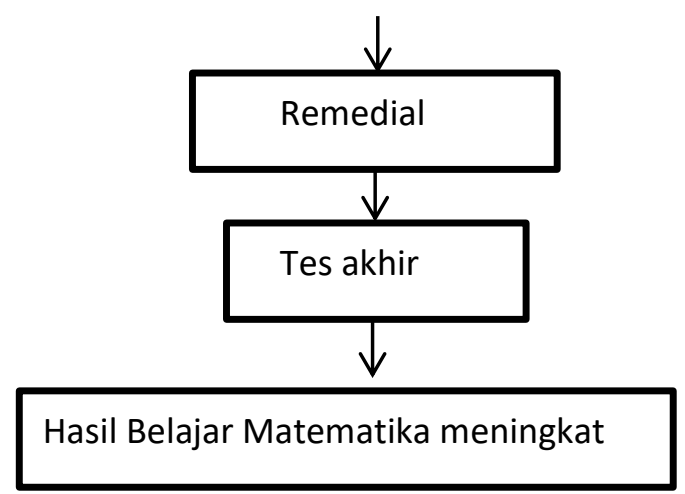

Gambar 2.1 Kerangka Pikir

\section{Hipotesis}

Berdasarkan permasalahan-permasalahan yang telah dikemukakan pada pembahasan sebelumnya, maka berikut ini akan dipaparkan suatu hipotesis sebagai jawaban sementara atas permasalahan yang ada.

Adapun hipotesis yang dimaksud adalah sebagai berikut :

- Ada pengaruh terhadap pemberian remedial lansung terhadap hasil belajar siswa pada mata pembelajaran matematika Kelas V SD Negeri Sikapa kabupaten Barru

\section{A. Rancangan Penelitian}

1. Jenis Penelitian

Jenis penelitian ini ialah penelitian pra-eksperimen (pra-eksprimen design). Rancangan ini digunakan untuk mengungkapkan hubungan sebab akibat hanya dengan cara melibatkan satu kelompok subjek, sehingga tidak ada kontrol yang ketat terhadap variabel.

Penelitian ini menggunakan pendekatan kuantitatif. Penelitian kuantitatif yaitu penelitian yang menggunakan data berupa angka sebagai alat untuk menemukan keterangan mengenai apa yang ingin diketahui yaitu pengaruh Remedial Lansung terhadap Hasil belajar Matematika murid kelas V adalah data kuantitatif. Data-data yang terkmpul sebagai hasil penelitian dianalisis dengan menggunakan metode statistik.

2. Lokasi dan waktu 
Penelitian ini dilaksanakan di SD Negeri Sikapa kabupaten Barru.Waktu penelitian direncanakan pada semester genap tahun ajaran 2017/2018 yang dimulai dengan observasi selama l-2 hari di SD Negeri Sikapa kabupaten Barru. dan waktu penelitian dilaksanakan selama 1-2 minggu. .

Berdasarkan observasi yang telah dilakukan pada tanggal 25 Januari 2017 bahwa murid kelas V SD Negeri Sikapa Kabupaten Barru. sangat rendah Hasil belajarnya pada mata pelajaran Matematika, hal ini disebabkan kurang adanya pemberian remedial pada pelajaran matematika oleh guru sehingga siswa kurang aktif dalam pembelajaran. Oleh karena itu, penulis disini ingin menerapkan pemberian Remedial lansung dan mengetahui hasil belajar matematika siswa.

3. Desain Penelitian

Desain penelitian ini menggunakan The One Group Pretest Posttest. Sebelum diberi perlakuan, kelompok diberi pre-test. Setelah hasil pre-test diperoleh maka kelompok baru diberi treatmen. Desain penelitian ini hanya menggunakan satu kelompok saja, sehingga tidak memerlukan kelompok kontrol.

Adapun desain penelitian ini adalah sebagai berikut:

$$
\mathrm{O}_{1} \longrightarrow \mathrm{X} \longrightarrow \mathrm{O}_{2}
$$

\section{Gambar 2.2 desain one group pretest posttest}

Keterangan:

$\mathrm{O}_{1}=$ Tes awal (pretest)

$\mathrm{O}_{2}=$ Tes akhir (posttest)

$\mathrm{X}=$ Perlakuan/ treatment Remedial Lansung

\section{B. Populasi dan Sampel}

\section{Populasi}

Populasi yaitu sekelompok orang, kejadian atau segala sesuatu yang mempunyai karakteristik tertentu (Indranata, 2008:172). Arti lain populasi seperti yang dikemukakan Hadi yaitu "Seluruh pendidik yang dimaksudkan untuk diselidiki yang paling sedikit mempuyai satu sifat yang sama". Dengan demikian populasi penelitian ini adalah semua murid kelas V SD Negeri Sikapa Kabupaten Barru, sebanyak 81 orang, laki-laki 51 orang dan perempuan 30 orang.

\section{Sampel}

Menurut Sugiyono (2016:62) Sampel adalah bagian dari jumlah dan karakteristik yang dimiliki oleh populasi. Sampel dalam penelitian diambil dengan menggunakan teknik sampling Probability Sampling yang meliputi Cluster ramdom sampling, di mana dalam pengambilan sampel di lakukan secara acak dari kelas I- 
VI SD Negeri Sikapa Kabupaten Barru. Setelah di lakukan teknik random, maka diperoleh sampel yaitu kelas V. Berikut adalah data Sampel Siswa SD Negeri Sikapa Kabupaten Barru.

\section{A.Definisi Operasional Varibel}

Melalui definisi operasional variabel, batasan istilah yang sesuai dengan judul penelitian akan dipaparkan guna memperjelas hasil penelitian.

\section{Pembelajaran Remedial Lansung}

Pembelajaran Remedial Lasung adalah pembelajaran yang bertujuan untuk memperbaiki sebagian atau seruluh kesulitan belajar yang di hadapi oleh siswa. Perbaikan diarahkan untuk mencapai hasil belajar yang optimal sesuai dengan kemampuan masing - masing siswa.

\section{Hasil belajar}

Hasil belajar adalah penguasaan pengetahuan atau keterampilan yang dikembangkan melalui mata pelajaran Matematika, yang ditunjukkan dengan nilai tes atau angka nilai dari pretest dan posttest yang diberikan oleh peneliti.

\section{Instrumen Penelitian dan Teknik Pengumpulan Data}

\section{A.Instrumen Penelitian}

Instrument yang digunakan dalam penelitian ini adalah:

\section{Tes Hasil Belajar}

Tes hasil belajar dengan jenis pretest dan posttest. pretest dilaksanakan sebelum menerapkan pembelajaran Remedial Lansung, sedangkan posttest dilaksanakan setelah murid mengikuti pembelajaran dengan menerapkan pembelajaran Remedial Lansung.

\section{Dokumentasi}

Dokumentasi digunakan untuk melengkapi data-data serta konsep-konsep mengenai kemampuan siswa terhadap pelajaran Matematika yaitu kemampuan Hasil belajar Siswa dalam pembelajaran Matematika.

\section{A.Teknik Pengumpulan Data}

Teknik yang digunakan peneliti dalam mengumpulkan data adalah sebagai berikut 


\section{Tes pretest dan Posttest}

a.Tes awal (pretest)

Tes awal dilakukan sebelum treatment/ perlakuan, pretest dilakukan untuk mengetahui kemampuan yang dimiliki oleh siswa sebelum Remedial Lansung b.Tes akhir (posttest)

Tes akhir dilakukan setelah treatment/ perlakuan, posttest ini bertujuan untuk mengetahui hasil belajar atau pengaruh Remedial Lansung.

\section{Dokumentasi}

Dokumentasi dilakukan dengan cara mengumpulkan dan menyimpan data. Data tersebut berupa nilai hasil belajar murid, absensi murid dan aktifitas mengajar guru, serta foto atau informasi dari berbagai sumber yang berkaitan erat dengan penelitian ini.

Dokumentasi digunakan untuk melengkapi data-data serta konsep-konsep mengenai kemampuan siswa terhadap pelajaran Matematika yaitu penerapan Remedial Lansung Terhadap Hasil Belajar

\section{Teknik Analisis Data}

\section{a. Uji Hipotesis}

Menggunakan rumus Paired Sample T-test:

$$
t_{\text {hit }}=\frac{\bar{D}}{\frac{S D}{\sqrt{n}}}
$$

Ingat :

$$
\begin{gathered}
S D=\sqrt{\operatorname{var}} \\
\operatorname{var}\left(S^{2}\right)=\frac{1}{n-1} \sum_{i=1}^{n}\left(x_{i}-\bar{x}\right)^{2}
\end{gathered}
$$

Keterangan :

$\mathrm{t}=$ nilai $\mathrm{t}$ hitung

$\mathrm{D}=$ rata-rata selisi pengukuran 1 dan 2

$\mathrm{SD}=$ standar deviasi selisi pengukuran 1 dan 2

$\mathrm{n}=$ jumlah sampel

Interpretasi : 
a. Untuk menginterpretasi uji t-tes terlebih dahulu harus ditentukan :

- $\quad$ Nilai signifikansi $\alpha$

- $\quad$ Df ( degree of freedom $)=\mathrm{N}-\mathrm{k}$, khusus untuk paired sample t-tes $\mathrm{df}=\mathrm{N}-1$

b. Bandingkan nilai thit dengan $\mathrm{t} t a b=\alpha: \mathrm{n}-1$

- Jika thit > ttab maka terdapat pengaruh Remedial Lansung terhadap Hasil Belajar pada Mata Pembelajaran Matematika Murid SD Negeri Sikapa Kabupaten Barru

Jika thit $<\mathrm{ttab}$ maka tidak ada pengaruh Remedial Lansung terhadap Hasil Belajar pada Mata Pembelajaran Matematika Murid SD Negeri Sikapa Kabupaten Barru.

\section{A. HASIL PENELITIAN DAN PEMBAHASAN.}

1. Gambaran umum lokasi penelitian

Penelitian yang dilaksanakan di SD Negeri Sikapa Kabupaten Barru terkait dengan metode mengajar yang diterapkan oleh guru dengan memberikan remedial lansung kepada siswa khususnya pada mata pelajaran Matematika. Hal ini mendapat respon positif dari pihak sekolah terutama oleh siswa, hal ini dibuktikan oleh adanya Tes Awal dan Tes Akhir yang telah dibagikan kepada 14 siswa sebagai sampel. SD Negeri Sikapa Kabupaten Barru didirikan pada tahun 1948 oleh PEMDA setempat. Sebagai sekolah dasar, SD Negeri Sikapa Kabupaten Barru memiliki fasilitas yang dapat dikategorikan sangat memadai dan mendukung berlangsungnya proses belajar mengajar yang kondusif, sekolah yang terletak di lokasi pedesaan yang terletak di jalan Allakangge Desa lompo tengah kecamatan Tanete Riaja Kabupaten Barru dengan luas $\pm 2.430 \mathrm{~m}^{2}$.

SD Negeri Sikapa Kabupaten Barru sejak awal sampai sekarang berstatus sebagai sekolah Negeri. SD Negeri Sikapa Kabupaten Barru memiliki tenaga pengajar 15 orang, dan memiliki 6 ruang kelas, 1 ruang kepala sekolah, 1 ruang perustakaan, 1 ruang gudang, dan 1 lapangan olah raga, 3 toilet.

Proses pembelajaran yang berlangsung di dalam kelas $\mathrm{V}$ sangat monoton, sehingga tidak ada feed back (umpan balik) dari murid, guru hanya menjelaskan sendiri tanpa melibatkan interaksi multi arah. Pemberian tugas tertulis secara terus menerus menyebabkan murid merasa bosan dalam kelas, murid kurang memperhatikan penjelasan guru, Siswa mengantuk dan mengobrol dengan teman sebangku,murid tidak aktif dalam bertanya serta berdiskusi dengan temannya, sehingga kemampuan berbicara Siswa terbilang sangat minim.

\section{A. Pembahasan}


Pada analisis pengaruh Remedil Lansung terhadap Hasil belajar Matematika terlihat bahwa nilai $t$ hitung yaitu 11,41 sedangkan $t$ tabel yaitu 2,16. Oleh karna itu, perbandingan $t$ hitung dengan $t$ tabel yaitu 11,41>2,16. Dengan demikian dapat diketahui bahwa $t_{\text {hitung }}$ lebih besar dari pada nilai $t_{\text {tabel. }}$

Berdasarkan kriteria pengujian hipotesis yaitu: Ada pengaruh Remedial Lansung terhadap Hasil belajar Mata Pembelajaran Matematika kelas V SD Negeri Sikapa Kabupaten Barru. Apabila nilai hitung lebih besar atau sama dengan nilai tabel, maka hipotesis yang berbunyi: tidak ada pengaruh Remedial Lansung terhadap Hasil belajar Mata Pembelajaran Matematika kelas V SD Negeri Sikapa Kabupaten Barru di tolak. Dengan demikian, maka hipotesis alternalitif yang berbunyi: terdapat pengaruh Remedial Lansung terhadap Hasil belajar Mata Pembelajaran Matematika kelas V SD Negeri Sikapa Kabupaten Barru di terima. Hal ini dapat dinyatakan bahwa Hasil belajar Matematika kelas V SD Negeri Sikapa Kabupaten Barru meningkat dengan diterapkannya Remedial Lansung.

\section{SIMPULAN DAN SARAN}

\section{A. Simpulan}

Berdasarkan hasil penelitian dan pembahasan dapat dismpulkan bahwa melalui penerapan Remedial Lansung terhadap Hasil belajar mata Pembelajaran

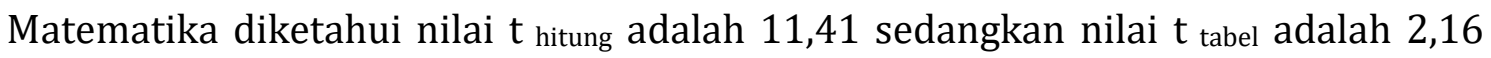
pada taraf signifikan 0,05 \%. Dengan demikian, hipotesis penelitian ini diterima,bahwa terdapat Pengaruh Remedial Lansung terhadap Hasil belajar pada Pembelajaran Matematika kelas V SD Negeri Sikapa Kabupaten Barru

Pengujian analisis data menunjukkan nilai $\mathrm{t}$ hitung sebesar 11,41 jumlah

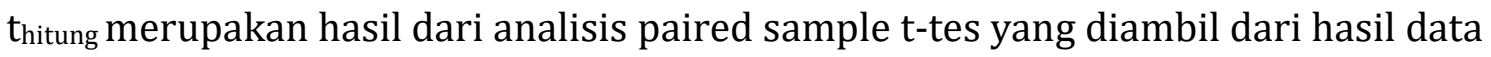
angket untuk mengetahui motivasi belajar IPS kelas $\mathrm{V}$, sedangkan nilai $\mathrm{t}$ tabel sebesar 2,16, hal ini dapat dilihat pada taraf signifikan 0,05 \% dengan $\mathrm{N}=14$.

Pengaruh Remedial Lansung terhadap hasil belajar mata pembelajaran Matematika kelas V SD Negeri Sikapa Kabupaten Barru, memiliki rata- rata yang cukup tinggi.

\section{B. Saran}

Berdasarkan simpulan di atas, ada beberapa saran dari penulis yaitu sebagai berikut: 
1. Guru dapat menerapkan remedial lansung sebagai alternatif pembelajaran matematika di kelas.

2. Hendaknya Siswa memiliki kebiasaan untuk menyampaikan pendapat baik melalui remedial lansung ataupun latihan agar kemampuan berfikir dan aktif berpartisipasi dalam proses pemebelajaran lebih meningkat.

3. Kepada Peneliti, diharapkan mampu menerapkan pemberian remedial lansung yang lebih baik lagi sehingga tercapainya tujuan pembelajaran yang diharapkan.

4. Kepada calon Peneliti, akan dapat lebih mengembangkan dan memperkuat remedial lansung yang diberikan serta memperkuat hasil penelitian ini dengan cara mengkaji terlebih dahulu dan mampu mengadakan penelitian yang lebih sukses.

\section{DAFTAR PUSTAKA}

Ahmad Abu dan Ubhiyati Nur,2001 ,Jakarta Ilmu Pendidikan, (PT. Rineka cipta,)

Imron Ali, 2012, Jakarta Manajemen Peserta Didik Berbasis Sekolah, ( Bumi Aksara)

Cece Wijaya,1996, bandung, Pendidikan Remedial Sarana Pengembangan mutu sumber daya manusia, (PT. RemajaRosdakarya,)

Cholid Narkubo,2001, jakarta Metologi Penelitian (Bumi Aksara, )

Depdiknas, 2004, jakarta, PedomanKenaikanKelas, (BumiAksara )

Depdikbud,1990,jakarta Kamus Besar Bahasa Indonesea, (PN. BalaiPustaka,)

Dimyati dan Mudjiono, 2002 jakarta BelajardanPembelajaran, (Rineka Cipta)

Mulyasa E.,2003,bandung,bantang ,Kurikulum Berbasis Kompetensi,

Emawati. 2012. Metode Penelitian. Jakarta: PT.Rineka Cipta.

Ahmadi H. Abu, 2004, jakarta, PsikologiBelajar, (RinekaCipta,)

Hartono, 2000 pekanbaru Strategi Pembelajaran, (LSFK2P) 
Heruman. (2007). Model Pembelajaran Matematika di SD. Bandung: Remaja Rosdakarya

Ischank S,W,2002, jogjakarta , Program remedial dalam proses belajar mengajar, (liberty,)

Karso. 2004. Pendidikan Matematika I. Jakarta: Universitas Terbuka

Mulyono Abdurrahman,2003.jakarta, Pendidikan bagi Berkesulitan Belajar, (Rineka Cipta,)

Sudjana Nana,2010,bandung, Penilaian Hasil Proses Bealajar Mengajar, (PT. Remaja Rosdakarya,)

Prihandoko, Antonius 2006. Memahami Konsep Matematika Secara Benar Dan Menyajikannya Dengan Menarik. Jakarta: Depdiknas.

Sugiyono. 2016. Metode Penelitian Kombinasi (Mixed Methods). Bandung: Alfabeta

Slameto, 1999 , jakarta Bimbingan di Sekolah, (PT. BinaAksara,).

Sanjaya, Wina. 2006. Pembelajaran dalam Implementasi Kurikulum Berbasis Kompetensi.Bandung: Kencana.

Sardiman. 2007. Interaksi dan Motivasi Belajar Mengajar. Jakarta: Raja Grafindo Persada.

Soemantri, Mulyani dan Permana, Johar. 1998/1999.Strategi Belajar Mengajar. Jakarta: Depdikbud.

Arikanto Suhaisimi, 2006, jakarta, Pengelolaan Kelas dan Siswa, (CV Rajawali,)

Suryabrata.2014. Metode Penelitian, Jakarta: Rajawali pers

Slameto, 2003, jakarta Belajardan factor-factor yang mempengaruhinya, (Rineka Cipta) Soedjaji. 2000. Kiat Pendidikan Matematika di Indonesia. Jakarta: Direktorat Jendral Pendidikan Tinggi Departemen Pendidikan Nasional 
Supatmono, Catur. 2009. Matematika Asyik. Jakarta: Grasindo 
